expertise in one of the following areas: Methods and Quantitative Techniques or Public Administration (with emphasis on public policy analysis); International Relations (with emphasis on conflict/peace analysis or futuristics); Comparative Politics (with emphasis on political economy); or Political Theory (with emphasis on positive theory).

Send applications as soon as possible to the Senior Assistant Registrat (Establishments), University of Ibadan, Ibadan, Nigeria.

University of Sierra Leone, Njala University College has announced the following openings to be filled as soon as possible:

- Senior Lecturer/Lecturer in the Educational Services Centre.

- Lecturer in the Department of Education. Must have higher degree in education and five years university teaching experience.

Write: the Secretary, University of Sierra Leone, PM Bag, Freetown, Sierra Leone.

The University of Juba (Sudan) is seeking candidates for four posts (Professor/Associate Professor/ Senior Lecturer/Lecturer) in the Language Centre. Preference will be given to candidates with ESP post-secondary experience in developing countries and either a M.A. in Applied Linguistics or a first degree in Science and TEFL degree or a one year TEFL Diploma. Appointees will be required to teach English service courses for preparatory and second year students in the Colleges of Natural Resources, Social Studies and Education. Send applications (2 copies) to the Secretary-General, University of Juba, P.O. Box 82, Juba, Sudan.

The University of Dar es Salaam (Tanzania) invites applications for the posts of Professor/Associate Professor/Senior Lecturer/Lecturer/Assistant Lecturer (3 posts) in the Department of History. Candidates should have a Ph.D. Appointees will be expected to teach one of the following: Economic History of East Africa with special reference to Tanzania; North African and African History; Chinese History. Contact the Chief Academic Officer, University of Dar es Salaam, P.O. Box 35091, Dar es Salaam, Tanzania.

The University of the West Indies (Trinidad) is seeking candidates for the following posts in the Institute of International Realtions:

- Professor/Senior Lecturer in International Law.

- Professor/Senior Lecturer in International Economic Relations.

- Senior Lecturer/Lecturer in International Relations in the Field of International Politics.

- Senior Library Assistant.

Send applications ( 2 copies) and names and addresses of three referees to the Chairman, Board of the Institute of International Relations, The University of the West Indies, St. Augustine, Trinidad.

The University of Zambia has announced the following openings to be filled as soon as possible:

- Senior Lecturer/Lecturer in the Department of Library Studies.

- Senior Research Rellow/Research Fellow in the Rural Development Studies Bureau (three posts).

All applications to the Registrar, University of Zambia, P.O. Box 2379, Lusaka, Zambia.

\title{
LETTER
}

The Library of Congress Washington, D.C. 20504

Dr. Vernon A. February

Visiting Associate Professor

August 7, 1978

Afro-American Studies Department

University of Wisconsin

Madison, Wisconsin 53706

Dear Dr. February:

This is in reference to your letter to the editor in the June 1978 issue of African Studies Newsletter concerning the list of "liberation support groups" that was published in the December 1977 issue. 
The list originally appeared as an appendix to a report on a publication survey trip to Great Britian and the Netherlands which I made in early 1977. As part of my effort to locate centers of African research and organizations concerned with sub-Saharan Africa, I visitd the headquarters of a number of groups in London, Amsterdam, and other cities. In my report, I describe the NederlandsZuidafrikaanse Vereniging and its affiliates as organizations whose "primary concerns are the cultural, historic, and linguistic ties between the Netherlands and South Africa." It is unfortunate that th is address list, when reproduced in part in the Africana Libraries Newsletter and subsequently in the African Studies Newsletter, was incorrectly identified by the editors as relating only to "liberation support groups." A more correct title would have been "Organizations in Great Britain and the Netherlands Concerned with African Affairs."

Thank you for bringing this matter to my attention. A copy of my trip report is enclosed.

Very truly yours, Julian W. Witherell

Chief, African and Middle Eastern Division

\section{LETTER/POSTS IN KENYA}

Edinburgh University Library George Square Edinburgh EH8 9LJ Scotland

African Studies Newsletter 28 July 1978

African Studies Association

Epstein Service Building

Brandeis University

Waltham, Mass. 02154

Dear Sir/Madam,

With reference to the statement of the Current Issues Committee on the arrest and detention of Ngugi wa Thiongo on p. 26 of the April News/etter, and the University of Nairobi's vacancy announcement on p. 23, you may be interested to note the following item, culled from the [British] Association of University Teachers Bulletin no. 72, June 1978, p. 5, among the "News from Headquarters, by the General Secretary":

\section{"POSTS IN KENYA}

At its recent meeting AUT Council noted that the African writer Ngugi wa Thiong'o who is head of the Department of Literatute at the University of Nairobi, has been imprisoned without trial in Kenya. AUT wishes to draw members' attention to this and before answering advertisements for academic posts at the University of Nairobi, contact should be made with AUT Headquarters."

Yours faithfully, L.A. Martin Sub-Librarian

\section{ASA SURVEY ON INVESTMENT IN SOUTH AFRICA}

\section{RESULTS}

At the end of March 1978, the African Studies Association Current /ssues Committee sent the following letter and questionnaire regarding investment in South Africa to 1,500 colleges and universities. A total of 128 responses have been received. 